\title{
Green, Two Components Highly Efficient Reaction of Ninhydrin with Aromatic Amines, and Malononitrile Using Ball-Milling Technique
}

\author{
H. A. Etman, H. M. Metwally, M. M. Elkasaby, A. M. Khalil, M. A. Metwally \\ Chemistry Department, Faculty of Science, Mansoura University, Mansoura, Egypt
}

\begin{abstract}
Ninhydrin (1) underwent several reactions with benzidine (2), o-phenylene diamine (4), p-toluidine (6) and malononitrile (9) for the purpose of producing novel indanedione derivatives of expected biological activity.
\end{abstract}

Keywords Green Chemistry, Ninhydrin, Aromatic Amines, Condensation Reactions

\section{Introduction}

The development of simple synthetic routes for widely used organic compounds from readily available reagents is one of the major tasks in organic synthesis. We report herein an efficient, solid-state synthesis of highly functionalized indan-1,3-diones via the reaction of ninhydrin with a variety of reagents as an extension to our previous work on the benign synthesis of these compounds [1a,b].

\section{Results and Discussions}

The easy access of a hydroxyl group of ninhydrin (1) to its substitution and the presence of carbonyl groups makes this highly reactive compound an interesting start point for cascade reactions with amino compounds[2].

Benzidine 2 condensed quantitatively with ninhydrin 1 at room temperature (molar ratio 1:1) in the solid state (ball milling) to give bis-azomethine 3 in $100 \%$ yield. The potential of the ball milling can be achieved by comparing the yield $\%$ of the same product 3 obtained when the reaction was carried out in solution ( $\mathrm{EtOH}-\mathrm{AcOH}$, ratio 7:3) or by grinding. The yield $\%$ in both cases reached to $60 \%$

The ball milling reaction of ninhydrin 1 with benzeidine 2 at room temperature afforded only the corresponding bis-azomethine 3 in a quantitative yield. The water of reaction was easily removed by heating to $80^{\circ} \mathrm{C}$ in a vacuum. The chemical structure of 3 was established on the basis of spectral data. The IR spectrum confirmed the presence of $-\mathrm{C}=\mathrm{N}$ and $\mathrm{C}=\mathrm{O}$ stretching absorption bands at 1608 , and $1718 \mathrm{~cm}^{-1}$. The ${ }^{1} \mathrm{H}-\mathrm{NMR}$ spectrum revealed the $\mathrm{ArH}$ at

* Corresponding author:

mamegs@mans.edu.eg (Mohamed Metwally)

Published online at http://journal.sapub.org/ajoc

Copyright (C) 2011 Scientific \& Academic Publishing. All Rights Reserved
7.3-8 ppm. The mass spectrum showed a molecular ion peak $\left(\mathrm{M}^{+}\right)$at $\mathrm{m} / \mathrm{z}=469.04\left(\mathrm{M}^{+}+1\right)$, corresponding to the molecular weight of the molecular formula $\mathrm{C}_{30} \mathrm{H}_{16} \mathrm{~N}_{2} \mathrm{O}_{4}=468.46$.<smiles>O=C1c2ccccc2C(=O)C1(O)O</smiles>

(1)

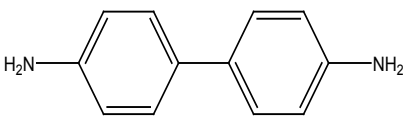

(2)

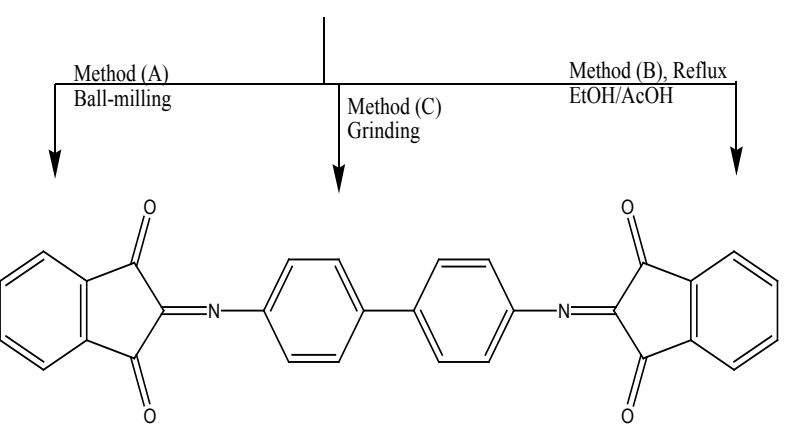

(3)
Reaction of ninhydrin 1 with an equimolar amount of benzidine 2 in EtOH/AcOH, (ratio 7:3) afforded the corresponding bis-azomethine 3 in $60 \%$ yield. The spectral data of azomethine 3 were in consistent with the structure. By analogy, grinding 1 and 2 in a mortar at room temperature for two hours resulted in the formation of 3 as inferred from its correct analytical and spectral data. In all three methods of synthesis, the m.p is the same.

The technique of waste-free solid-state reaction could be applied to prepare the intramolecular bis-azomethine 5. It has been reported that stochiometric runs by the ball milling of ninhydrin 1 with o-phenylene diamine 4 afforded the corresponding pyrazine derivative 5 with $100 \%$ yield without the aid of any catalysts or solvents.

The 4-cascades of 1 with o-phenylenediamine 4, reported by Kauppp[2] are fully regiospecific and also quantitative 
upon milling at $-5^{\circ} \mathrm{C}$ and drying at $80^{\circ} \mathrm{C}$ in vacuum. Our method is an easy access to 5 with well-defined substitution at room temprature. A reasonable sequence of events is addition to $\mathrm{C}=\mathrm{O}$, substitution of $\mathrm{OH}$ and two eliminations of water<smiles>O=C1c2ccccc2C(=O)C1(O)O</smiles>

(1)<smiles>Nc1ccccc1N</smiles>

(4)

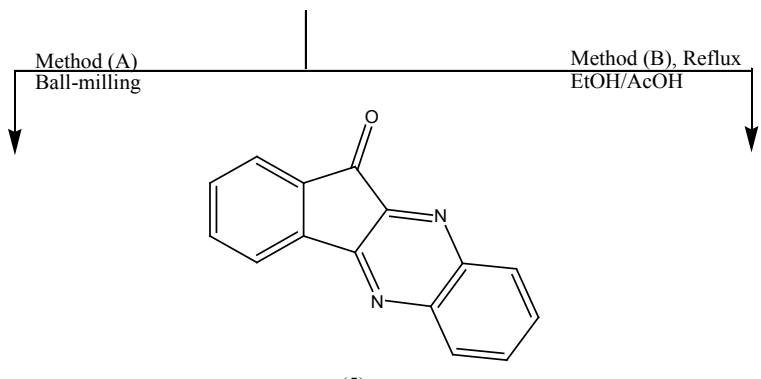

(5)
Further evidence for the formation of 5 was gained from its synthesis in $(\mathrm{EtOH} / \mathrm{AcOH}$, ratio $7: 3)$ in $60 \%$ yield, $\mathrm{mp}$ and mixed mp. The formation of 5 finds support from the correct analytical and spectral data.

The IR spectrum confirmed the presence of $-\mathrm{C}=\mathrm{N}$ and $\mathrm{C}=\mathrm{O}$ absorption bands at $1604,1727 \mathrm{~cm}^{-1}$. The ${ }^{1} \mathrm{H}-\mathrm{NMR}$ spectrum revealed the ArH at $\delta$ 7.2-8.1 ppm. The mass spectrum showed a molecular ion peak $\left(\mathrm{M}^{+}\right)$at $\mathrm{m} / \mathrm{z}=232.33$ corresponding to the molecular weight of the molecular formula $\mathrm{C}_{15} \mathrm{H}_{8} \mathrm{~N}_{2} \mathrm{O}=232.24$.<smiles>O=C1c2ccccc2-c2nc3ccccc3nc21</smiles>

(5)<smiles>Cc1ccc(N)cc1</smiles>

(6)

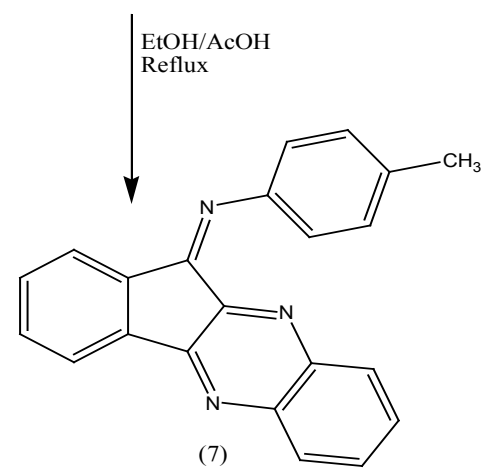

As a further extension for the above successful reactions, it seemed of interest to react the pyrazine 5 with p-tolidine 6 by refluxing in $\mathrm{EtOH} / \mathrm{AcOH}$ (ratio 7:3) to give compound 7 . The formation of 7 finds support from the correct analytical and spectral data. The IR spectrum confirmed the presence of $-\mathrm{C}=\mathrm{N}$ absorption band at $1614 \mathrm{~cm}^{-1}$. The mass spectrum showed a molecular ion peak $\left(\mathrm{M}^{+}\right)$at $\mathrm{m} / \mathrm{z}=321.43(100 \%)$ corresponding to the molecular weight of the molecular formula $\mathrm{C}_{22} \mathrm{H}_{15} \mathrm{~N}_{3}=321.37$.

p-Toulidine 6 condensed quantitatively with ninhydrine 1 at room temperature (molar ratio 1:1) in the solid state (ball milling) to give the azomethine 8 in $100 \%$ yield. The potential of the ball milling can be achieved by comparing the yield $\%$ of the same product 3 obtained when the reaction was carried out in solution ( $\mathrm{EtOH}-\mathrm{AcOH}$, ratio 7:3) or by grinding. The yield $\%$ in both cases reached to $60 \%$.

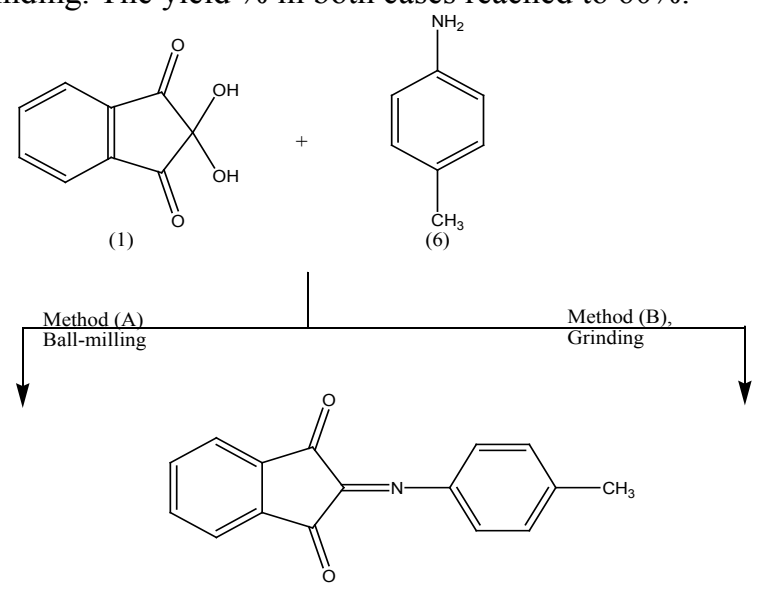

(8)

The ball milling reaction of ninhydrin 1 with p-toulidine 6 at room temperature afforded only the corresponding azomethine 8 in a quantitative yield. The water of reaction was easily removed by heating to $80^{\circ} \mathrm{C}$ in a vacuum. The chemical structure of 8 was established on the basis of spectral data. The IR spectrum confirmed the presence of $-\mathrm{C}=\mathrm{N}$ and $\mathrm{C}=\mathrm{O}$ stretching absorption bands at $1592,1710 \mathrm{~cm}^{-1}$. The mass spectrum showed a molecular ion peak $\left(\mathrm{M}^{+}\right)$at $\mathrm{m} / \mathrm{z}=$ $249.18(75.2 \%)\left(\mathrm{M}^{+}\right)$, corresponding to the molecular weight of the molecular formula $\mathrm{C}_{16} \mathrm{H}_{11} \mathrm{NO}_{2}=249.18$.

It has been reported $[3,4]$ that reaction between ninhydrin (1) and malononitrile (9) in clay or $\mathrm{H}_{2} \mathrm{O}$ yield compound (10) in $80 \%$ yield, and we found that reaction between (1) and (9) without the aid of any catalyst and by using ball-milling yields the same product in $100 \%$ yield.<smiles>CC(=O)C1C(=O)c2ccc(Br)cc2C1=O</smiles>
(1) (9)

(10)

The formation of (10) finds support from its analytical and spectral data; the IR spectrum showed absorption band at (1707 and $2200 \mathrm{~cm}^{-1}$ ) for $\mathrm{C}=\mathrm{O}$ and $\mathrm{C} \equiv \mathrm{N}$.

The ${ }^{1}$ HNMR spectrum showed bands at $\delta$ 7.4-8.4 ppm for Ar-H and the mass spectrum exhibited the molecular ion peak at $\mathrm{m} / \mathrm{z}=208.74\left[\mathrm{M}^{+}\right]$corresponding to the molecular weight of the molecular formula $\mathrm{C}_{12} \mathrm{H}_{4} \mathrm{O}_{2} \mathrm{~N}_{2}=208.17$

By repeating the above reaction in $(\mathrm{EtOH} / \mathrm{AcOH}$ ratio $7: 3)$ it gives compound (11). 


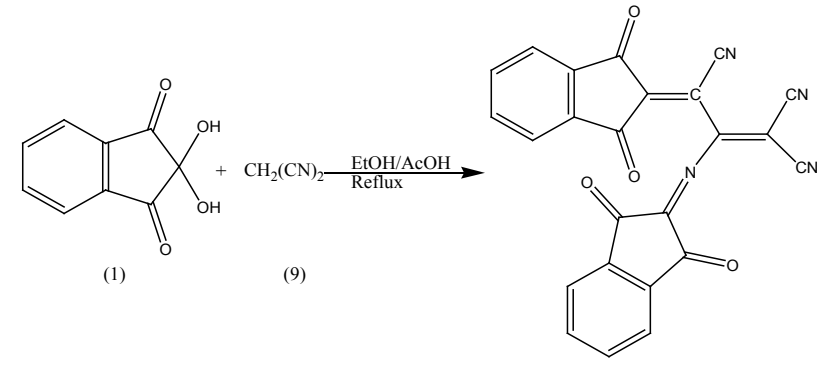

(11)

We provides a plausible mechanism;
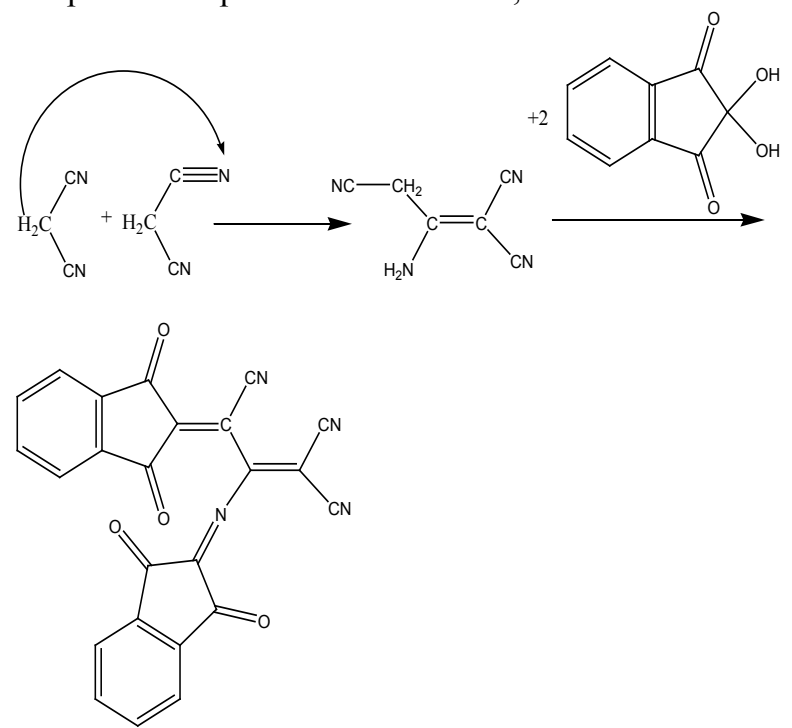

(11)

The formation of (11) finds support from its analytical and spectral data; the IR spectrum showed absorption band at (1706 and $2196 \mathrm{~cm}^{-1}$ ) for $\mathrm{C}=\mathrm{O}$ and $\mathrm{C} \equiv \mathrm{N}$.

The ${ }^{1}$ HNMR spectrum showed bands at $\delta$ 7.5-8.3 ppm for $\mathrm{Ar}-\mathrm{H}$ and the mass spectrum exhibited the molecular ion peak at $\mathrm{m} / \mathrm{z}=416.38\left[\mathrm{M}^{+}\right]$corresponding to the molecular weight of the molecular formula $\mathrm{C}_{24} \mathrm{H}_{8} \mathrm{O}_{4} \mathrm{~N}_{4}=416.38$.

\section{Experimental}

Melting points are uncorrected and were determined with a Fisher-Johns melting point apparatus. Elemental analyses were carried out at Microanalytical Unit of the Faculty of Science, Mansoura University; the results were in satisfactory agreement with the calculated values. IR spectra $(\mathrm{KBr})$ were recorded with 5000 FTIR spectrometer (not all frequencies are reported). The ${ }^{1} \mathrm{H}$-NMR spectra were acquired using a Bruker WP 300 spectrometer at $300 \mathrm{MHz}\left({ }^{1} \mathrm{H}\right)$ or $75.5 \mathrm{MHz}\left({ }^{13} \mathrm{C}\right)$ in broad band mode. Mass spectra were obtained at a Finnigan MAT 212 instrument by electron impact at $70 \mathrm{eV}$. The ball-mill was a Retsch MM 2000 swing mill with a $10 \mathrm{~cm}^{3}$ stainless steel, double-walled beaker with fittings for circulating coolants. Two stainless steel balls of $12 \mathrm{~mm}$ diameter were used. Ball-milling was performed at $20225 \mathrm{~Hz}$ frequency, usually at room temperature (without circulating liquid and the temperature did not rise above $\left.30^{\circ} \mathrm{C}\right)$.
Reaction of ninhydrin 1 with benzidine 2: Formation of 3 Method (A); Ball-milling

A mixture of $356 \mathrm{mg}$ of ninhydrin $1(2.00 \mathrm{mmol})$ and 184 $\mathrm{mg}$ of benzidine $2(1.00 \mathrm{mmol})$ was ball-milled at room temperature for $1 \mathrm{~h}$. The material obtained was dried at 0.01 bar at $80{ }^{\circ} \mathrm{C}$ in vacuum to give pure 3 with $100 \%$ yield and did not require purifying workup.

Method (B); Using Solvent

A mixture of $356 \mathrm{mg}$ of ninhydrin $1(2.00 \mathrm{mmol})$ and 184 $\mathrm{mg}$ of benzidine $2(1.00 \mathrm{mmol})$ was refluxed in $10 \mathrm{ml}$ absolute $\mathrm{EtOH}$ and $2 \mathrm{ml}$ glacial $\mathrm{AcOH}$ for $10 \mathrm{hrs}$, left to cool. The ppt. formed filtered off and left to dry, recrystallize from $\mathrm{EtOH}$, to give pure 3 with $60 \%$ yield.

Method (C); By Grinding

A mixture of $178 \mathrm{mg}$ of ninhydrin $1(1.00 \mathrm{mmol})$ and 184 $\mathrm{mg}$ of benzidine $2(1.00 \mathrm{mmol})$ was grinded in a mortar at room temperature for $30 \mathrm{~min}$, material obtained was dried at 0.01 bar at $80{ }^{\circ} \mathrm{C}$ in vacuum to give pure 3 with $60 \%$ yield and did not require purifying workup.

The product 3

Brownish powder mp $300^{\circ} \mathrm{C}$; IR $(\mathrm{KBr}): \bar{v} 1718(\mathrm{C}=\mathrm{O})$, $1608(\mathrm{C}=\mathrm{N}) \mathrm{cm}^{-1} ;{ }^{1} \mathrm{H}$ NMR $\left(200 \mathrm{MHz},\left[\mathrm{D}_{6}\right] \mathrm{DMSO}, 25^{\circ} \mathrm{C}\right.$, TMS) $\delta=7.50-8.00(\mathrm{~m}, 7 \mathrm{H}, \mathrm{ArH}) \mathrm{ppm}$. MS (EI, $70 \mathrm{eV}): \mathrm{m} / \mathrm{z}$ $(\%)=469.04\left[\mathrm{M}^{+}\right] . \mathrm{C}_{30} \mathrm{H}_{16} \mathrm{~N}_{2} \mathrm{O}_{4}(468.46)$ : calcd. C $76.92 \mathrm{H}$ 3.44 N 5.98 O 13.66; found C 67.93 H 3.40 N 5.95 O 13.72.

Reaction of ninhydrin 1 with o-phenylenediamine 4, formation of 5

Method (A); Ball-milling

A mixture of $178 \mathrm{mg}$ of ninhydrin $1(1.00 \mathrm{mmol})$ and 108 $\mathrm{mg}$ of o-phenylenediamine $4(1.00 \mathrm{mmol})$ was ball-milled at room temperature for $1 \mathrm{~h}$. The material obtained was dried at $0.01 \mathrm{bar}$ at $80{ }^{\circ} \mathrm{C}$ in vacuum to give pure 5 with $100 \%$ yield and did not require purifying workup.

Method (B); Using Solvent

A mixture of $356 \mathrm{mg}$ of ninhydrin $1(2.00 \mathrm{mmol})$ and 216 $\mathrm{mg}$ of o-phenylenediamine $4(2.00 \mathrm{mmol})$ was refluxed in 10 $\mathrm{ml}$ absolute $\mathrm{EtOH}$ and $2 \mathrm{ml}$ glacial $\mathrm{AcOH}$ for $5 \mathrm{hrs}$, left to cool. The ppt. formed filtered off and left to dry, recrystallize from $\mathrm{EtOH}$, to give pure 5 with $60 \%$ yield.

The product 5

Green powder mp 227-229 $\mathrm{C}$; IR (KBr): $\bar{v} 1727(\mathrm{C}=\mathrm{O})$, $1650(\mathrm{C}=\mathrm{N}) \mathrm{cm}^{-1} ;{ }^{1} \mathrm{H}$ NMR $\left(200 \mathrm{MHz}, \mathrm{CDCl}_{3}, 25^{\circ} \mathrm{C}, \mathrm{TMS}\right) \delta$ $=7.50-8.50(\mathrm{~m}, 8 \mathrm{H}, \mathrm{ArH}) \mathrm{ppm}$. MS $(\mathrm{EI}, 70 \mathrm{eV}): \mathrm{m} / \mathrm{z}(\%)=$ $232.33\left[\mathrm{M}^{+}\right] . \mathrm{C}_{15} \mathrm{H}_{8} \mathrm{~N}_{2} \mathrm{O}$ (232.24): calcd. C $77.58 \mathrm{H} 3.47 \mathrm{~N}$ 12.06 O 6.89; found C 78.01 H $3.42 \mathrm{~N} 12.03$ O 7.00.

Reaction of product 5 with p-toulidine 6 : formation of 7

A mixture of $696 \mathrm{mg}$ of product $5(3.00 \mathrm{mmol})$ and $321 \mathrm{mg}$ of p-toulidine $6(3.00 \mathrm{mmol})$ was refluxed in $10 \mathrm{ml}$ absolute EtOH and $2 \mathrm{ml}$ glacial AcOH for 3 hours, left to cool. The ppt. formed filtered odd and left to dry, recrystallize from EtOH, to give pure 7 .

The product 7

Reddish orange powder mp $195^{\circ} \mathrm{C}$; IR (KBr): $\bar{v} 1650$ $(\mathrm{C}=\mathrm{N}) \mathrm{cm}^{-1}$. MS (EI, $\left.70 \mathrm{eV}\right): \mathrm{m} / \mathrm{z}(\%)=321.43(100 \%)\left[\mathrm{M}^{+}\right]$. $\mathrm{C}_{15} \mathrm{H}_{8} \mathrm{~N}_{2} \mathrm{O}$ (321.37): calcd. C $82.22 \mathrm{H} 4.70 \mathrm{~N} 13.08$; found $\mathrm{C}$ $82.25 \mathrm{H} 4.74 \mathrm{~N} 13.13$. 
Reaction of ninhydrin 1 with p-toulidine 6 : Formation of 8 Method (A); Ball-milling

A mixture of $356 \mathrm{mg}$ of ninhydrin $1(2.00 \mathrm{mmol})$ and 214 $\mathrm{mg}$ of p-toulidine $6(2.00 \mathrm{mmol})$ was ball-milled at room temperature for $1 \mathrm{~h}$. The material obtained was dried at 0.01 bar at $80{ }^{\circ} \mathrm{C}$ in vacuum to give pure 8 with $100 \%$ yield and did not require purifying workup.

Method (B); By Grinding

A mixture of $356 \mathrm{mg}$ of ninhydrin $1(2.00 \mathrm{mmol})$ and 214 $\mathrm{mg}$ of p-toulidine $6(2.00 \mathrm{mmol})$ was grinded in a mortar at room temperature for $30 \mathrm{~min}$, material obtained was dried at 0.01 bar at $80{ }^{\circ} \mathrm{C}$ in vacuum to give pure 8 with $60 \%$ yield and did not require purifying workup.

The product 8

Brownish powder mp $85-90^{\circ} \mathrm{C}$; IR $(\mathrm{KBr}): \bar{v} 1710(\mathrm{C}=\mathrm{O})$, $1590(\mathrm{C}=\mathrm{N}) \mathrm{cm}^{-1}$. MS (EI, $\left.70 \mathrm{eV}\right): \mathrm{m} / \mathrm{z}(\%)=249.07$ (61.7\%)[M $\left.\mathrm{M}^{+}\right] \mathrm{C}_{16} \mathrm{H}_{11} \mathrm{NO}_{2}$ (249.26): calcd. C $77.10 \mathrm{H} 4.45 \mathrm{~N}$ $5.62 \mathrm{O} 12.84$; found C 77.12 H 4.50 N $5.64 \mathrm{O} 12.81$.

Reaction of ninhydrin 1 with malononitrile 9: Formation of 10

Method (A); Ball-milling

A mixture of $534 \mathrm{mg}$ of ninhydrin $1(3.00 \mathrm{mmol})$ and 198 $\mathrm{mg}$ of malononitrile $9(3.00 \mathrm{mmol})$ was ball-milled at room temperature for $1 \mathrm{~h}$. The material obtained was dried at 0.01 bar at $80{ }^{\circ} \mathrm{C}$ in vacuum to give pure 10 with $100 \%$ yield and did not require purifying workup.

Method (C); By Grinding

A mixture of $534 \mathrm{mg}$ of ninhydrin $1(3.00 \mathrm{mmol})$ and 198 $\mathrm{mg}$ of malononitrile $6(3.00 \mathrm{mmol})$ was grinded in a mortar at room temperature for $30 \mathrm{~min}$, material obtained was dried at 0.01 bar at $80{ }^{\circ} \mathrm{C}$ in vacuum to give pure 10 with $60 \%$ yield and did not require purifying workup.

The product 10

Green powder mp $210-213^{\circ} \mathrm{C}$; IR (KBr): $\bar{v} 1707(\mathrm{C}=\mathrm{O})$,
2229, $2200(\mathrm{C} \equiv \mathrm{N}) \mathrm{cm}^{-1} ;{ }^{1} \mathrm{H}$ NMR $\left(200 \mathrm{MHz}, \mathrm{CDCl}_{3}, 25^{\circ} \mathrm{C}\right.$, TMS) $\delta=7.50-8.50(\mathrm{~m}, 8 \mathrm{H}$, ArH) ppm. MS (EI, $70 \mathrm{eV}): \mathrm{m} / \mathrm{z}$ $(\%)=208.74\left[\mathrm{M}^{+}\right] . \mathrm{C}_{12} \mathrm{H}_{4} \mathrm{~N}_{2} \mathrm{O}_{2}$ (208.17): calcd. C $69.24 \mathrm{H}$ $1.94 \mathrm{~N} 13.46 \mathrm{O} 15.37$; found C $69.26 \mathrm{H} 1.93 \mathrm{~N} 13.51 \mathrm{O}$ 15.40 .

Method (B); Using Solvent

A mixture of $891 \mathrm{mg}$ of ninhydrin $1(5.00 \mathrm{mmol})$ and 990 $\mathrm{mg}$ of malononitrile $6(5.00 \mathrm{mmol})$ was refluxed in $10 \mathrm{ml}$ absolute $\mathrm{EtOH}$ and $2 \mathrm{ml}$ glacial AcOH for $8 \mathrm{hrs}$, left to cool. The ppt. formed filtered off and left to dry, recrystallize from $\mathrm{EtOH}$, to give pure 11 with $60 \%$ yield.

The product 11

Greenish powder $\mathrm{mp} 243-245^{\circ} \mathrm{C}$; IR (KBr): $\bar{v} 1633$ $(\mathrm{C}=\mathrm{N}), 1672,1706,1745,1767(\mathrm{C}=\mathrm{O}), 2196,2217(\mathrm{C} \equiv \mathrm{N}) \mathrm{cm}^{-1}$; ${ }^{1} \mathrm{H}$ NMR $\left(200 \mathrm{MHz}, \mathrm{CDCl}_{3}, 25^{\circ} \mathrm{C}\right.$, TMS $\delta=7.50-8.50$ $(\mathrm{m}, 8 \mathrm{H}, \mathrm{ArH}) \mathrm{ppm}$. MS (EI, $70 \mathrm{eV}): \mathrm{m} / \mathrm{z}(\%)=416.38\left[\mathrm{M}^{+}\right]$. $\mathrm{C}_{24} \mathrm{H}_{8} \mathrm{~N}_{4} \mathrm{O}_{4}$ (416.34): calcd. C $69.24 \mathrm{H} 1.94 \mathrm{~N} 13.46 \mathrm{O} 15.37$; foun

\section{REFERENCES}

[1] a-H.A. Etman, H.M. Metwally, M.M. Elkasaby, A.M. Khalil and M.A. Metwally, Chemistry of Heterocyclic Compounds, accepted for publication, 2011. b-A. Etman, H.M. Metwally, M.M. Elkasaby, A.M. Khalil and M.A. Metwally, Quimica no Brasil, accepted for publication, 2011

[2] G.Kaupp, MR Naimi-Jamal, J. Schmeyers, 2002, Chem. Eur. J. 8:594

[3] M. Chakrabarty; A. Mukherji ; S. Arima ; Y,. Harigaya ;G. Pilet; Monatsh Chem (2009) 140:189-197

[4] A. Schônberg, E.Singer (1970) Chem Ber 103:3871 